\title{
NOTAS SOBRE A PRODUÇÃO FEMININA DA SOCIALIDADE SEGUNDO O PONTO DE VISTA DE UM BEBEDOR DE CAIÇUMA
}

\author{
Marcos de Almeida Matos (D)
}

Universidade Federal do Acre I Laboratório de 


\section{RESUMO}

Partindo da descrição de uma festa de iniciação feminina, este artigo procura esboçar algumas ideias acerca dos modos pelos quais as mulheres contribuem na produção cotidiana da socialidade. Entre os diversos produtos da ação feminina, o texto busca colocar em relevo dois: a produção do corpo de outras mulheres mais jovens que passam pela menarca e a produção da caiçuma, especialmente da caiçuma fermentada, que constitui um dos principais catalisadores da socialidade.

Palavras-chave: iniciação feminina; caiçuma; produção.

\section{NOTES ON THE FEMININE PRODUCTION OF SOCIALITY, FROM THE PERSPECTIVE OF A CAIÇUMA DRINKER}

Starting from the description of a female initiation party, the article seeks to outline some ideas about the ways in which women contribute to the daily production of sociality. Among the various products of female action, the text seeks to highlight two: the production of the body of other younger women going through the menarche, and the production of “caiçuma”, especially fermented "caiçuma", which is one of the main catalysts of sociality.

Keywords: female initiation;

\section{NOTAS SOBRE LA PRODUCCIÓN FEMENINA DE LA SOCIABILIDAD, DEL PUNTO DE VISTA DE UN BEBEDOR DE CAIÇUMA}

A partir de la descripción de una fiesta de iniciación femenina, el artículo busca esbozar algunas ideas sobre las formas en que las mujeres contribuyen a la producción diaria de la sociabilidad. Entre los diversos resultados de la acción femenina, el texto busca destacar dos: la producción del cuerpo de otras mujeres más jóvenes que pasan por la menarquia, y la producción de "caiçuma", especialmente "caiçuma" fermentada, que es uno de los principales catalizadores de la sociabilidad.

Palabras clave: iniciación femenina; caiçuma, producción 


\section{INTRODUÇÃO}

Durante todo o trabalho de campo que subsidiou a escrita de minha tese de doutorado, realizada entre os Manxineru do alto rio $\mathrm{Iaco}^{1}$, eu recebi muitos convites para participar de diversos tipos de festa ou comemoração, o que me fez logo perceber que de tédio ninguém sofria naquela terra indígena. O que todas essas comemorações tinham em comum - e que, portanto, poderiam ser tomadas como critérios definidores do que pode ser chamado de "festa" era a oferta generosa de grandes quantidades de caiçuma fermentada e a dança ao som das músicas (geralmente forrós, bregas, cúmbias ou carimbós) tocadas pelos aparelhos de som, comprados de ambulantes peruanos ou bolivianos na fronteira. Os motivos para a comemoração eram os mais variados, mas havia um que se sobressaía em razão do interesse que despertava nos meus amigos indígenas: as chamadas "festas de pintação", ou hapijihlu, em língua manxineru.

Partindo da descrição de uma das "festas de pintação" das quais participei, neste artigo procuro sugerir algumas ideias sobre a importância do trabalho feminino na composição dos coletivos e de suas relações². Essas ideias, é claro, estão marcadas por sua origem em uma perspectiva particular: a de um tomador de caiçuma forte.

\section{A FESTA DE PINTAÇÃO OU HAPIJIHLU}

Foi em uma manhã ensolarada de novembro, enquanto eu realizava o já costumeiro trabalho de apoio à escola da aldeia Extrema, que um dos professores com os quais eu cooperava me transmitiu o convite de seu pai, me pedindo ainda para confirmar se eu estaria mesmo presente na "festa de pintação" (ou hapijihlu, em manxineru) de uma de suas irmãs. $\mathrm{O}$ amigo professor, que me transmitira o convite, aproveitou para me avisar que ele estaria ausente por alguns dias, uma vez que ele, os seus irmãos e cunhados empreenderiam sucessivas incursões para pescar e caçar rio acima, com o objetivo de prover "rancho" para a festa organizada por seu pai. Ele me explicou, então, que, nessas ocasiões, o pai da menina que será pintada, juntamente como os seus filhos e genros e outros braços com os quais ele pode contar, se encarrega de caçar e pescar para conseguir comida o suficiente a ser oferecida aos convidados da festa.

1 Os Manxineru constituem uma população de aproximadamente 1.200 pessoas falantes de uma língua arawak, e vivem majoritariamente na Terra Indígena Mamoadate, às margens do alto rio Iaco, afluente do rio Purus, no estado do Acre. A língua falada pelos Manxineru se aproxima muito daquela que é falada pelas populações que se autointitulam Yine no Peru, com as quais os Manxineru partilham histórias e trajetórias. Os artigos e as monografias de Peter Gow sobre os Piro do Baixo Urubamba, bem como a tese de doutorado de Minna Opas, que trabalhou com os Yine da comunidade de Diamante, na região do rio Madre de Dios, constituem apoios comparativos importantes para a compreensão dos Manxineru brasileiros (alguns desses trabalhos estão elencados na bibliografia).

2 Para uma abordagem indígena desses mesmos temas, ver Brasil (2017). 
Meu amigo professor me explicou, ainda, que naquele mesmo dia ele iria de bote até algumas aldeias rio abaixo, para falar com as pessoas que $\mathrm{o}$ seu pai mandava convidar ou para mandar recados para elas. A festa seria realizada para a pintação de duas meninas, uma era sua irmã e a outra era uma de suas sobrinha $\left(Z D^{3}\right)$. A festa de pintação é pensada por todos como um evento que deve reunir gente de perto e de longe, e ninguém promove tal tipo de evento se não for para convidar as pessoas de outras aldeias. Esse costume, de convidar (ou mandar um emissário convidar) parentes que vivem distante ou em outras aldeias, dá à festa um sentido político eminente, conferindo a ela papel importante na determinação dos grupos locais como conjuntos em relação recíproca.

Toda festa sempre desperta muito interesse entre jovens e adultos, mas as festas de pintação são especialmente comentadas e aguardadas com ansiedade por quem foi convidado. Todas as pessoas consideradas parentes próximos ou genealógicos do casal de pais da menina e todos aqueles com os quais os dois têm relações afetivas são convidados. Nos dias subsequentes, o ter sido convidado ou não apareceu como tema de muitas conversas casuais das quais tomei parte - algumas pessoas me diziam, com certa apreensão, por exemplo: "ele (i.e., o pai da moça) ainda não me convidou, mas eu acho que vai convidar, então eu vou".

Quando eu voltei para a casa na qual vivia hospedado, soube que o meu anfitrião, que era compadre do pai de uma das meninas à qual a festa era dedicada, fora convidado para "tirar jenipapo" para as meninas. Ofereci-me para ir junto dele, e alguns dias depois nós visitamos diversos pés de jenipapo ao redor da aldeia, em busca de frutos grandes e bonitos o suficiente para a ocasião. Meu anfitrião me explicou que o jenipapo usado na iniciação feminina deve ser sempre previamente retirado do pé por um homem especialmente convidado pelos pais da garota para essa função. Ele não deve ser preguiçoso e não pode ter sido vítima de acidentes ofídicos. O jenipapo deve ser retirado do pé e colocado diretamente em uma cesta ou um saco, sem cair no chão. Esses cuidados, ele me explicou, têm como objetivo preservar a longevidade da menina em iniciação: se forem contrariados, ela terá uma vida curta ou será desanimada, doente e preguiçosa.

Quando fomos entregar os frutos de jenipapo para a mãe de uma das garotas que seriam pintadas, observei que a garota já havia superado a parte mais rigorosa da reclusão. Uma das tias dela fez questão de me explicar o processo da reclusão

3 Como glosa aos termos de parentesco, adoto, por comodidade, a notação inglesa convencional, tomando-a como ferramenta heurística e meramente tradutória para esta exposição. Não é meu objetivo sugerir a verdade subjacente de um modelo genealógico. 
pubertária das meninas: quando a menina menstrua pela primeira vez, seus pais a colocam em reclusão. Tradicionalmente, a sua mãe ou uma de suas avós "trepam" ela (como me foi explicado em português): ela deve permanecer deitada em uma rede amarrada no alto, próximo ao teto da casa, em um cômodo ou canto da casa cujo acesso possa ser restringido. Ela permanece deitada a maior parte do tempo, até o seu segundo período menstrual. A menina é assistida o tempo todo por sua mãe ou avó, que se encarrega de auxiliá-la em sua higiene pessoal, e a alimenta, sempre com líquidos. Ela não deve beber água, caso em que sua menstruação se transformaria em uma séria hemorragia, colocando sua saúde em risco. Ao invés disso, ela mata a sua sede com mingau de banana verde (sapnaha). No começo da reclusão, a menina não deve ser vista por qualquer pessoa, mas apenas pelas mulheres que cuidam dela ou por seus familiares mais próximos. Ela deve evitar o contato com qualquer homem que não seja seu parente próximo (i.e., seu pai e seus irmãos).

A partir de sua segunda menstruação, a menina já pode descer da rede, mas seu resguardo e a sua reclusão continuam. Ela cumpre uma rigorosa dieta, que mobiliza inúmeros cuidados voltados para a aquisição de certos comportamentos ou capacidades e para a evitação de outros tantos. Entende-se que o seu corpo e os seus ossos estão moles e que, por isso, o que ela faz durante esse período molda-os para sempre (cf. Belaunde 2003:139). A consideração desse conjunto de procedimentos empreendidos durante a reclusão feminina demonstra a pertinência da afirmação de McCallum, para quem o gênero pode ser compreendido como conhecimento corporificado (McCallum 2001:5; Belaunde 2006:215).

Alguns alimentos são oferecidos a ela com o propósito de engordá-la: tornando-se gorda, ou ganhando corpo, ela adquire progressivamente uma visibilidade ideal, que será exposta aos convidados em sua festa. Sua dieta preferencial é composta por certas espécies de macacos, como o macacode-cheiro, que lhe transmite prontidão, velocidade, esperteza e uma boa dose de desconfiança. O macaco-preto é evitado, pois seus braços são finos e fracos, e o macaco-capelão também não deve ser consumido, porque tem as suas costas curvadas, o que prejudicaria a postura da inicianda. Ela não come carne de jabuti, pois a ele é reputado ser preguiçoso. A carne da anta é permitida, pois se trata de um animal corpulento. Durante a primeira fase da reclusão, a menina só sai de sua rede para fazer suas necessidades. Caso fique andando, me disseram, ela atrai insetos, cobras peçonhentas e onças que desejam lhe fazer mal, ou melhor, que desejam a menina e o seu sangue: a menina está em vias de se tornar o que há de mais bonito e desejável. 
Ao menstruar pela segunda vez, ela pode descer da rede, e as regras de sua reclusão se tornam mais brandas ${ }^{4}$. Ela pode circular por perto de sua casa, e pode ajudar sua mãe nas tarefas domésticas, mas sem trabalhar muito. A moça deve andar com um pano amarrado na cabeça ${ }^{5}$, caso contrário urubus podem fazer cocô sobre ela, o que logo deixaria seus cabelos brancos e a faria envelhecer mais rápido. Também é levada algumas vezes para a floresta por sua avó ou sua mãe, onde, longe de olhares de pessoas estranhas, recebe sucessivos banhos com ervas e plantas escolhidas com a finalidade de moldar seu corpo e lhe transmitir disposição, ânimo, força, beleza. Linhas são amarradas em seus braços e pernas, junto às suas principais articulações, para conferir-lhe força física e estâmina. Essas linhas não podem ser cortadas nem intencionalmente quebradas: elas devem ficar no corpo até arrebentarem naturalmente. A menina também passa a andar com um pequeno gancho feito de madeira de canela-de-velho pendurado no pescoço, e só pode se coçar com ele, caso contrário as marcas de sua unha em sua pele podem se transformar em estrias (que, segundo a explicação de um amigo, se estão em sua barriga ou tronco podem se tornar também "caminhos" pelos quais ela poderia abortar seus primeiros filhos). A corda onde pendia a forquilha ao redor do seu pescoço também será posteriormente amarrada em seus pulsos e joelhos.

A justificativa mais comum que ouvi para todos esses cuidados é o desejo de garantir a longevidade e a saúde permanente da mulher. As mulheres que cumprem a reclusão, depois de "formadas" (talpokotatka, em língua Manxineru), estão mais protegidas, adoecem menos e afastam a agressividade das cobras peçonhentas e das onças. Além disso, o resguardo faz com que ela não tenha preguiça, não seja demasiadamente envergonhada ou tímida, e que se torne capaz de preparar grandes quantidades de caiçuma de boa qualidade $^{6}$. A semiótica ${ }^{7}$ da reclusão pubertária

4 Doravante, a mulher, sempre que ficar menstruada, deverá tomar alguns cuidados: se ela preparar caiçuma, a bebida ficará intragável; se ela for ao roçado ou mexer em alguma planta cultivada, a planta morrerá ou não crescerá como deveria. Além disso, os homens devem evitar fazer sexo com mulheres menstruadas, caso contrário ficarão "empanemados" (mpasuatu).

5 É muito comum a exigência de cobrir a cabeça da menina que precisa ir a algum lugar durante a reclusão, ainda que os motivos alegados variem (cf., por exemplo, Lima 2005:152; Maizza 2012:104).

$6 \mathrm{O}$ que, em certo sentido, denota metonimicamente a capacidade de nutrir adequadamente os parentes que vivem juntos em uma casa, pelo fabrico da caiçuma doce (tepalha potshwalu, em língua Manxineru), mas também a capacidade de promover a abertura das unidades familiares para visitas dos afins, através do oferecimento de caiçuma fermentada (tepalha katsholu, em língua Manxineru).

7 Utilizo aqui a ideia de semiótica como a manipulação significativa de matérias e princípios, e não apenas como um sistema significante. Inspiro-me, ao fazê-lo, no uso de Lima (2005:137, 140, 145), depois de Deleuze \& Guattari 
parte do reconhecimento de que o corpo é constituído através da relação dos genitores e da criança com múltiplas agências, humanas e extrahumanas. Assim, durante a reclusão, essas relações constituintes devem ser, em parte, reconstruídas e, em parte, substituídas por novas relações. As práticas da reclusão estão baseadas na consciência da necessidade e da possibilidade de agir sobre esses tipos de relação.

De qualquer forma, após a menina deixar a reclusão, os seus pais podem querer fazer uma "festa de pintação". Soube de vários casos nos quais os cuidados da reclusão foram cumpridos, mas não se realizou nenhuma festa em seu término. A festa seria a melhor maneira de terminar o período de formação da menina, mas não parece ser compulsória e, tendo em vista o trabalho que envolve a sua execução, muitos pais optam por não a fazer'. Quando escolhem fazê-la, como no caso que relato, algumas semanas após o final da primeira fase da reclusão da menina, seus pais começam a preparar a festa. Enquanto os homens se encarregam de prover suficiente carne de caça e pescado, a dona da casa, com a ajuda da inicianda, começa o preparo de muita caiçuma, que deverá fermentar o suficiente, para que fique bem forte ou azeda (tepalha katsholu). Todas as mulheres envolvidas no feitio da caiçuma ficam em abstinência sexual desde os dias do preparo até o dia da festa, caso contrário a caiçuma ficaria pastosa e cheia de gomas, inadequada ao consumo. Além disso, todos os envolvidos na produção da festa, especialmente os pais da menina, devem evitar sentir raiva ou se envolver em brigas durante o trabalho, pois, se não, seus convidados podem sentir ganas de brigar ou se desentender durante a festa, sinal inequívoco de mal agouro para a inicianda.

Quando o dia marcado para a festa finalmente chegou, fui avisado de que deveria ir para a casa que a sediaria por volta das nove horas da manhã. Naquela manhã, bem cedo, eu soube depois, as meninas (uma é MZ da outra) foram levadas para um lugar previamente escolhido e preparado na mata por três mulheres que cuidaram de seus resguardos durante a reclusão: a $M$ de uma, MM da outra; a MM de uma, MMM da outra; e a FM de uma delas. Todas elas eram mulheres com mais de 50 anos: a iniciação conecta dois extremos geracionais, ao condicionar os cuidados dispensados por mulheres na menopausa para

(1995), que elaboram a ideia de uma "máquina abstrata semiótica" que distribui regimes de signos e regime de corpos sobre os estratos de que se formam os conjuntos e as coisas.

8 Gow (2001:178) afirma que os anfitriões da festa deveriam convidar todos os Piro, o que, em meados da década de 80 , envolveria ser capaz de produzir quantidades absurdas de comida e de caiçuma para oferecer, sendo esta uma das razões para o abandono da festa. 
meninas na menarca. Lá, elas receberam um banho com infusões de diversas ervas e folhas, e seus corpos foram inteiramente pintados com padrões geométricos (no rosto, o do tamboatá, tsojiri; no corpo, o do jabuti, knoya, e da jiboia, mapyolo), com a tintura de jenipapo. Disseramme que a tintura, feita com aqueles frutos de jenipapo especialmente colhidos, deve estar bem preparada, e que se ela ficar bem escura no corpo da menina, contrastando com a pele embranquecida pelos dias de reclusão, longe do sol, significa que ela viverá uma vida longa e saudável (para a qual contribuem os padrões dos animais escolhidos, especialmente da jiboia e do jabuti, reputados seres resistentes e longevos).
Além das pinturas de jenipapo, as meninas tiveram as franjas de seus cabelos cortadas na altura do meio da testa (o que, certamente, destacava a beleza de seus rostos). Os cabelos cortados foram dispostos pelas iniciandas longe dos olhos das pessoas e em um lugar onde eles não poderiam ser pisados ou mexidos por alguém .

Enquanto as meninas estavam na mata, os convidados foram chegando e iam sendo acomodados aos poucos. Alguns rapazes jogavam futebol, outros, dominó na sala da casa. Não era oferecida caiçuma a ninguém, pois não se deve tomar caiçuma antes da apresentação das meninas: são elas que vão servir as primeiras rodadas da

9 Não faltam exemplos dessa prática de corte de cabelos das meninas que passaram pela menarca entre os conjuntos indígenas na Amazônia ocidental. Em sua monografia sobre os Kanamari, Costa (2007:328-329) observou que as meninas que cumprem a reclusão da menarca (cujo principal objetivo também parece ser o de preservar a juventude e a saúde da mulher que se forma) devem cortar seus cabelos, pois, caso contrário, eles crescerão frágeis e grisalhos, índices do envelhecimento precoce da mulher. Entre os Kanamari, o cabelo é um indicador da saúde do corpo. Além disso, e de um modo geral, o cabelo estaria também ligado às potências espirituais do sangue (por isso, o homicida também corta seu cabelo, visando suavizar os efeitos do sangue do morto, que infecta seu corpo). Harry Walker também observou a alegação dos Urarina de que a menina que deixa a reclusão da menarca deve ter os seus cabelos cortados, caso contrário eles ficarão descoloridos e fracos (Walker 2013:105). Entre os Jarawara, no médio Purus, as meninas, na reclusão da menarca, cortam seus cabelos bem curtos (Maizza 2012:104). Há uma relação difusa (e, creio poder afirmar, extremamente difundida) entre o cabelo e o sangue, sobre a qual atualmente possuo apenas algumas pistas. Certa vez, por exemplo, vi um manxineru colocar pedaços de seu próprio cabelo cortado com um terçado sobre um ferimento na perna de seu sobrinho, para estancar o sangramento. Além disso, a ligação entre o corte dos cabelos e o luto é comum na Amazônia (cf. Ewart 2013a:102). Minna Opas afirma que, em Diamante (comunidade Yine-Piro, às margens do rio Madre de Dios), as pessoas dizem se reconhecer pelo corte de cabelo, e que, por isso, quando morre algum parente próximo, deve-se cortar o cabelo bem curto (Opas 2008:100). Os Ashaninka com os quais Weiss trabalhou também afirmaram cortar os cabelos de todos os familiares próximos de um parente morto, para evitar a morte de outra pessoa e para garantir que a alma do morto não reconheça os que ficaram vivos (Weiss 1975:434). Entre os Piro do baixo rio Urubamba, o sangue está ligado à vitalidade e às capacidades produtivas: dizse que a vitalidade e a força dos jovens decorrem da pujança do sangue em seu corpo (Gow 1991:129). Da mesma forma, o fluxo de sangue está diretamente envolvido na capacidade transformacional dos corpos, e qualquer tipo de hemorragia reata a ligação entre os espíritos para além dos corpos construídos coletivamente (cf. Belaunde 2006). O ritual da menarca visa o controle do fluxo menstrual pelo fortalecimento do corpo da menina. Essa constituição de um corpo forte e saudável se dá de maneira indissociável em relação à consolidação de um conjunto de parentes que partilha comida e cuidados (especialmente, neste caso, dos cuidados dispensados por suas parentes ascendentes que estão na menopausa). O corte dos cabelos no encerramento da reclusão se relaciona, assim, ao controle do fluxo de sangue, à consolidação de um corpo saudável e à consequente restrição das transformações indesejáveis. 
bebida, já que são as donas da caiçuma. Às 10 horas da manhã, aproximadamente, as duas meninas e as suas iniciadoras saíram da mata ${ }^{10}$, anunciadas pelos sopros de uma buzina simples feita de taboca e pelos fogos de artifício. Elas se colocaram uma ao lado da outra no pátio em frente à casa. Todos rodearam as meninas em silêncio, que eram assim explicitamente exibidas aos presentes. Elas tinham o corpo todo pintado, vestiam shorts e bustiê vermelhos, e usavam alguns poucos colares e pulseiras de miçanga. O pai de uma das meninas e avô da outra, dono da casa na qual se realizava a festa, me pediu repetidamente para que eu as fotografasse, insistindo que eu deveria "colocar aquelas imagens em um livro" ${ }^{11}$, o que contrastava com a discrição e mesmo a desconfiança que as pessoas geralmente demonstram diante dos brancos munidos de câmeras fotográficas. As meninas estavam ali para serem vistas por todos.

Uma das mulheres iniciadoras (FM de uma delas) fez um breve discurso em manxineru, falando que as meninas tinham finalmente saído da reclusão, que estavam ali, que a festa tinha muita gente e muita caiçuma forte e as pessoas não deveriam brigar, pois ali eles são todos parentes. $\mathrm{O}$ pai de uma das meninas (e MF da outra), dono da casa na qual se realizava a festa, repetiu, em língua portuguesa, uma parte do que havia sido dito pela mulher, acrescentando uma sincera admoestação: "nem todo mundo que está aqui eu convidei, mas tudo bem, vai ter comida para todo mundo" (ele é monolíngue em português). Suspeito que ir a festas sem ter sido convidado é uma experiência comum e mesmo vivida como divertimento pelos rapazes que, aos olhos do anfitrião, estão ali apenas para namorar e/ou para brigar.

Da mesma forma, nas outras "festas de pintação" das quais participei - e, mais geralmente, em todas as festas maiores que juntavam parentes de diferentes procedências -, os anfitriões sempre fizeram seus breves discursos no início da ocasião, comentando a fartura da comida e da caiçuma

10 Em língua manxineru, "sair" traduz-se por rijpaka. Gow (2016) demonstrou a importância do campo semântico conotado por esse verbo: "Essas palavras piro derivam do verbo gishpaka, 'emergir, passar de um estado interior para um estado exterior'. 'Emergir' é um ato generativo potente na vida social de Piro. Um bebê Piro não nasce, mas 'emerge' no campo social de seus parentes em potencial. O bebê é o agente de seu nascimento e não é, como no idioma inglês, levado a nascer. Além disso, o ponto alto da vida ritual dos Piro ocorre quando a garota sai de seu isolamento da puberdade, coberta de desenhos pintados, jóias de prata, colares de contas, sinos e chocalhos presos ao seu braço e perna (pogi-, 'dando a conhecer, fazendo um som'). Ela é, naquele momento, a apoteose visual e auditiva da beleza de Piro, e seu surgimento inicia o kigimawlo, 'enfeites de miçangas são colocados nela', o ritual de iniciação das meninas" (Gow 2016, a tradução, como dos demais textos citados cujo original está em língua estrangeira, é de minha responsabilidade). Dos indígenas em "isolamento voluntário", por vezes, também se diz que "saíram", isto é, que apareceram na margem do rio e que foram vistos.

11 O que acabei fazendo quando foi publicado o "Plano de Gestão da Terra Indígena Mamoadate" (Manxineru 2016), no qual consta uma foto das meninas recém-saídas da reclusão. 
fermentada (ou se desculpando pela eventual limitação de seus recursos), e recomendando a boa relação entre os convivas, enfatizando que "todos são parentes" e que, por isso, não deveriam ocorrer brigas (mas as brigas sempre ocorrem). Esse tipo de fala, como mostrou Gow (1991), redirecionando as intuições clastreanas sobre o "discurso vazio" do chefe ameríndio (cf. Clastres 2003:172), busca contrapor aos perigos da bebedeira (os casos extraconjugais, as fugas de jovens filhas, as brigas etc.) uma estética da vida em comum, e constituise, assim, como vetor de produção da comunidade (Gow 1991:226-228)12. A posição ativa assumida por esses anfitriões em sua relação com quem participa da festa é o protótipo de toda comunidade - e o mesmo se poderia dizer do mutirão, do jogo de futebol ou de qualquer tipo de trabalho coletivo.

Naquela festa, após as palavras do dono da casa e da avó (FM) de uma das meninas que se "pintaram", as meninas foram orientadas a entrar na casa, mas não pela porta da cozinha (uma delas se dirigiu para lá e foi reconduzida a outra porta, que franqueava a uma grande sala). Dentro da casa, na ampla sala do anfitrião, fez-se uma fila com alguns homens mais velhos, convidados para tomar a primeira rodada de caiçuma que seria servida pelas meninas. Eu estava entre as pessoas chamadas a compor essa fila. As meninas, então, vieram carregando baldes de plástico repletos de caiçuma forte. Elas serviam, cada uma com uma pequena panela, cada um dos presentes na fila. Eles tomavam metade do que era oferecido por elas, e elas terminavam o conteúdo da cuia, passando a servir o seguinte na fila. Depois disso, o dono da casa gritou que seria oferecida uma rodada geral, e as meninas passaram a servir caiçuma para todos, homens e mulheres que demonstrassem vontade de beber. Nessa rodada, elas não bebiam mais.

Depois dessa segunda rodada, a festa foi explicitamente começada. Os irmãos e os tios (MB) das iniciandas se apressaram em buscar uma grande caixa amplificada, na qual colocaram para tocar forrós e bregas gravados em pen-drives ou cartões de memória. Nesse momento, as meninas, ainda paramentadas, dançaram diante de todos "uma parte" (como se diz em português) com alguns de seus parentes mais velhos (tios - FB ou MB, irmãos, pai, avô...). Mas poucas pessoas, além dos pares formados pelas meninas que deixaram a reclusão, se arriscavam a dançar nesse momento da festa, pois a bebedeira apenas tinha começado. O pai de uma das meninas, genro do dono da casa, arrumou sobre uma grande grelha os pedaços

12 Surrallés (2003:132) fez uma interessante análise das formas de diálogo que abrem a beberagem de caiçuma entre os Candoshi, discursos que, mais do que dizer alguma coisa, funcionam pragmaticamente para abrir o espaço no qual podem circular palavras e caiçuma, substância da socialidade que se estabelece entre os afins. 
do boi que matara para a ocasião, e começou a assar e a oferecer carne para os presentes. Todos dispararam a tomar caiçuma forte, e quem tinha álcool (chamado regionalmente de "tampinha azul") bebia e oferecia para seus amigos mais próximos. Ao contrário da caiçuma, cujas doses rodam publicamente e são quase obrigatórias para todos os homens adultos, o álcool circula discretamente, e é sempre considerado muito pouco para tanta gente. Os rapazes voltaram ao jogo de futebol.

A tarde prosseguiu animada e, quando ia anoitecendo, as pessoas começaram a se organizar para o forró. A festa, então, se esvaziou, para ser povoada novamente pelas pessoas bem vestidas e perfumadas, calçadas com sapatos ou tênis, que iam enchendo a sala. Alguns pares foram se formando na pista de dança, puxados pelas meninas que saíram da reclusão (agora, elas se apresentavam de banho tomado, já vestidas em suas melhores roupas), e a festa continuou num crescendo de animação. À medida que a noite prosseguia, casais eram discretamente formados pelos cantos da festa, e rapidamente sumiam. Os menos animados iam se retirando para seu pouso aos poucos. Os mais resistentes continuaram a beber até o outro dia. E o forró não parava.

Quando amanheceu, a churrasqueira foi acesa outra vez. A festa continuava para quem queria ainda ouvir música e beber. Algumas pessoas foram se arrumando para ir embora. Outras diziam que iam dar um pulo em casa e voltar. No meio da manhã, o campo de futebol voltou a ser usado pelos meninos e rapazes. E assim se passaram dois dias. A festa foi encerrada apenas quando toda a caiçuma havia sido consumida.

Depois da festa, as meninas foram consideradas "formadas" (em manxineru, talpokotatka, ou pode-se dizer também, em um sentido mais geral, makloji, que traduz-se por "jovem” ou "moça”), e puderam abandonar os cuidados da reclusão. Dizer que a moça está formada é também um jeito de dizer que ela está apta para relacionar-se sexualmente. Rapazes comentavam comigo, por exemplo, que "fulano tem duas filhas formadas", motivo pelo qual, brincavam, eles desejavam ir até a sua casa beber caiçuma. A partir desse momento, pensa-se que as mulheres estão preparadas para viver uma vida longa e saudável. Ter o corpo (-mane) e os ossos (-hapu) fortes, objetivos da manipulação semiótica de substâncias e do corpo da menina, é condição para tomar parte nas atividades produtivas femininas. Com efeito, as mulheres caracterizam suas atividades produtivas principais (carregar água, partir lenha, buscar e carregar cultivares no roçado) como dispêndios de força, e dar à luz também é pensado como fazer força. A capacidade de fazer força está nos ossos 
da mulher, que, junto à sua postura - que lhe permite carregar pesados volumes apoiados sobre a sua cabeça ou nos cestos atados com envira à sua testa -, é trabalhada durante a reclusão da menarca (cf. Belaunde 2003:137-138).

\section{NÃO CONTROLAR, MAS, ANTES, PRODUZIR E ABRIR}

Alfred Métraux talvez tenha sido o primeiro a observar, em 1945, a generalidade dessas práticas de iniciação ou de cuidados após a menarca. Seu trabalho apontou, de forma pioneira, para a grande difusão e coincidência de uma série de cuidados voltados ao corpo da inicianda, visando a sua proteção contra "perigos sobrenaturais" (Métraux 2013:335). Não obstante seu pioneirismo, ele exemplifica também a comum tendência dos antropólogos para analisar esse tipo de conjunto de práticas iniciatórias como tentativas de (re)produzir e estender o controle que uma sociedade exerceria de maneira mais ou menos eficaz sobre a natureza.

Gerald Weiss, por exemplo, fez uma descrição sumária da reclusão feminina entre os Ashaninka ribeirinhos, e descreveu práticas muito semelhantes àquelas relatadas entre os Piro por Peter Gow e a essa que descrevo aqui. Ele afirma que o objetivo da reclusão é "engordar a garota, e forçar ela a aprender a trabalhar e a não ser preguiçosa, aprender a fiar e aprender a obedecer ao seu futuro marido" (Weiss 1975:241). Em nosso contexto eu não poderia concordar com esta ênfase no controle das mulheres pelos homens, dado que a reclusão parece estar muito mais ligada ao desenvolvimento da força do corpo e dos ossos, das capacidades, bem como à longevidade e ao consequente bem-estar das mulheres (em certo sentido, a reclusão é operada por mulheres para as mulheres). Interpretar os procedimentos da reclusão pubertária feminina como formas de efetivar o controle das mulheres pelos homens seria compartilhar dos mesmos pressupostos que, mostrou-nos Strathern (1988), inviabilizaram a compreensão dos ritos de iniciação melanésios. Trata-se daquilo que ela denomina de "paradigma do controle social da natureza" (Strathern 1988:107): a combinação da ideia de que o ritual objetiva constituir uma ordem social que se impõe sobre uma natureza ou individualidade recalcitrante (a natureza, o corpo, a mulher etc.); e a ideia de que há uma separação entre domínios da vida social que se articulam hierarquicamente (o doméstico e o público), o que aprisiona a antropologia em uma analítica do controle (dos homens sobre as mulheres, cf. Strathern 1988:99101). Naturalmente, afirma Strathern (1988:103), a atenção dos melanésios não recai sobre os problemas envolvidos na formação de sociedade (i.e., no controle "social" de uma "natureza", seja do corpo, seja das mulheres), mas, antes, sobre 
questões ligadas à eficácia dos procedimentos rituais: "como extrair do corpo aquilo que ele é capaz de fazer”. O mesmo poderia ser dito sobre a reclusão pubertária que descrevemos. E, entre essas capacidades do corpo que se produz feminino, está a de prover uma das principais substâncias produtoras do aquecimento de relações e da abertura dos grupos locais: a caiçuma forte (em manxineru, tepalha katsholu).

Peter Gow (2001:158-182), em sua análise da kigimawlo, sugere a ligação do ritual com três narrativas míticas: a história do nascimento de Tsla, a história das irmãs Kochmaloto e as histórias que narram o relacionamento da lua com uma mulher humana ${ }^{13}$. Segundo ele, o ritual projeta a viabilidade do "mundo vivido Piro" adiante, no espaço e no tempo (Gow 2001:158), respondendo à condição de mortalidade dos homens (que difere tanto da resiliência miraculosa de Tsla, quanto da hipermortalidade das irmãs Kochmaloto - Gow 2001:133). O ritual faz isso constituindo-se como um cenário que tem em seu centro o encerramento de uma etapa da construção do corpo da mulher, construção empreendida com o auxílio de uma semiótica apoiada sobre aqueles mitos. Mas, é claro, o ritual faz mais do que encerrar a construção do corpo da garota:

O kigimawlo, ao proporcionar à menina uma 'vida longa', permite que o povo Piro efetue todas as mudanças necessárias para garantir a produção contínua de seu mundo vivido, apesar dessa mortalidade. Ao celebrar o controle da iniciada sobre seu sangue menstrual, o ritual estabelece as condições para seu futuro controle sobre o fluxo de caiçuma nos rituais de iniciação de suas filhas e, ainda mais no futuro, seu controle sobre o fluxo de desenhos pintados para tornar as meninas da geração de suas netas bonitas para seus rituais de iniciação. Da mesma forma, o ritual estabelece as transformações nas relações de parentesco que permitem as relações sexuais e a afinidade real, transformando 'parentes distantes' em maridos e esposas reais e outros afins. $\mathrm{O}$ ritual transforma o distanciamento temporal dos laços familiares na gênese dos futuros laços familiares, criando novas relações sexuais. Reunidos na casa grande onde se faz o kigimawlo, todo o povo Piro ao longo do rio gera novamente as condições para sua redispersão ao longo do rio (Gow 2001:176)

Em outras palavras, trata-se de uma festa dedicada também à composição de relações de afinidade, o que poderia ser constatado, como mostra Gow, pela análise das músicas que eram cantadas na ocasião, as quais colocam em cena, através de típicas reversões de perspectiva (procedimento muito explorado pelas artes vocais ameríndias), as relações entre genros e sogras (ou sobrinhos, BS, e tias, FZ - Gow 2001:171-173). Além

13 As três histórias sofreram sensíveis transformações entre os Manxineru, como era de se esperar. Na maior parte das versões que ouvi, a história das irmãs Kochmaloto funde-se com a do nascimento de Tslatu (como é chamado esse importante personagem mítico no alto Iaco), e a história da lua contada ali é semelhante àquela registrada entre os povos Pano, no Purus - por exemplo, por Siskind (1973:47-48), entre os Sharanawa (cf. também Calavia Sáez 2006:397-398; D’ans 1975:113-122). 
disso, a partir da associação entre a superfície pintada das kusmas e dos corpos e a pele da onçapintada (kayonalu mhenoklu) e da jiboia (mapyolo), Gow sugere que um aspecto central do ritual estaria no momento da recepção dos convidados, no qual os anfitriões apareceriam como seres bonitos, mas de certo modo ameaçadores, tais quais jaguares e anacondas:

as decorações corporais do povo Piro em reuniões rituais transformam sua aparência cotidiana na aparência de onças. A aparência cotidiana está ligada ao nshinikanchi, à "mente, memória, pensamento, amor, respeito", que governa as relações cotidianas entre os corresidentes. Anfitriões e convidados, no entanto, por definição não são corresidentes e, quando se reúnem coletivamente, aparecem entre si sob formas de onça, para marcar e efetivar a natureza perigosa desse tipo de reunião. Essa transformação exterior é o produto de gimatkalchi, 'conhecimento', o conhecimento dos desenhos que as mulheres têm em suas cabeças. É o prelúdio para uma transformação interior adicional, à medida que anfitriões e convidados começam a beber caiçuma (Gow 2001:121-122).

Assim, segundo Gow (2001:124), ao se assemelharem temporariamente às onças no ritual, os Piro adquirem ou constituem aquilo que esses animais perderam no mito de nascimento de Tsla (para que os humanos a tivessem): uma vida social. Em que pese as transformações pelas quais os mitos recrutados por Gow passam quando os contextualizamos no alto rio Iaco (cf. M. Matos 2018a), penso que o sentido geral de suas análises permanece pertinente para a reclusão feminina e a "festa de pintação" entre os Manxineru. Com efeito, a longevidade que se busca conquistar durante a reclusão e em seu término decorre, em parte, do posicionamento a meio termo entre a longevidade sobre-humana e a transformabilidade da anaconda (da sucuri ou da jiboia) e a mortalidade imposta às onças de bando no mito. Assim, poder-se-ia traçar paralelos fenomenológicos entre o ato de "trepar" ou "subir" a menina e a situação pela qual passam as irmãs no mito de nascimento de Tslatu, que sobrevivem à enchente "trepando" em um pé de jenipapo. Não por acaso, a menina que deixa a reclusão poderá ter seu corpo pintado de jenipapo com os padrões gráficos (yonawlu) da jiboia. A "festa de pintação" que encerra a reclusão evoca também algo do cenário perigoso e excitante vivenciado pela mãe de Tslatu, quando ela é recebida na casa das onças de bando, com a grande diferença de que, agora, é a menina que está em casa, e é ela que recebe seus afins para oferecer-lhes caiçuma.

O ritual kigimawlo foi pensando por Gow como um dos três eixos de "transformações de transformações" analisados por ele: desenhos e vestimentas vão se articulando com a escrita e a roupa dos brancos; cosmologia e escatologia dão lugar a um xamanismo ayahuasqueiro que compõe com as formas de cristianismo que se difundiram 
pela Amazônia ocidental; e o ritual de iniciação feminina vai cedendo seu lugar às formas de escolarização e às festas das comunidades nativas.

Nos três casos, segundo Gow, trata-se de formas ativas de acomodar a presença dos brancos e de suas mercadorias no mundo vivido piro, presença que só fez aumentar desde a primeira metade do século XIX. No centro desses processos está a questão do conhecimento e as suas transformações (Gow 2001).

A análise de Gow nos ajuda a entender como kusmas, panelas e potes pintados, mas também as músicas da festa, puderam ser substituídos pelas mercadorias dos brancos (que, em manxineru, são chamados payri). Assim, a aparência que se assume nas festividades estaria relacionada ao outro tipo de ser perigoso que são os payrune (ou "brancos") ${ }^{14}$, mas a adoção dessa aparência também está condicionada pelo conhecimento, não mais das pinturas, mas aquele vinculado pela escola, que é parte do que permite adquirir roupas e mercadorias em relações em certa medida pacíficas e produtivas com esses estrangeiros. O uso das roupas dos brancos estaria associado ao aprendizado de um outro tipo de desenho, diferente do desenho tradicional das mulheres Piro: os desenhos dos brancos, a escrita (no baixo
Urubamba, kajitu yona - Gow 2001:127; no alto Iaco, yonawlu, exatamente como são designados os desenhos "tradicionais"). Trata-se de uma transformação da transformação: a pintura e o uso da kusma eram transformações do corpo; a adoção da roupa dos brancos é uma transformação dessa transformação (Gow 2001:127). Subjacente está um princípio largamente compartilhado pelos coletivos amazônicos: agir com eficácia envolve sempre integrar ou absorver a capacidade agentiva de entidades reputadas como proficientes nas atividades relevantes, sendo a imitação ou a assunção das formas estéticas dessas entidades (i.e., o seu corpo como feixe de afetos) um princípio "metodológico" fundamental. A eficácia dessa adoção de formas estéticas alheias está diretamente ligada à sua capacidade de elicitar ações ou respostas daqueles diante dos quais o imitador se posiciona, isto é, em induzir o interlocutor a ocupar uma posição determinada, formatando o contexto da interação.

A mudança de potes, kusmas e músicas cantadas para panelas, roupas e músicas de branco tem um sentido não trivial, uma vez que está associada a uma narrativa que explica a mudança histórica: o uso da roupa dos brancos no lugar dos modos

14 Que onças e estrangeiros ou brancos possam entreter uma relação paradigmática foi sugerido por Dona Valquíria Manchineri, em um depoimento transcrito por Mercante (2000:89-90): "Essa é uma história de uns bichos que acabaram com muitos de nossa nação. Como os bolivianos, esses bichos mataram muitos de nós. Essa é a história das onças de bando, que acabaram com muitos dos antigos". Em outro contexto, Costa (2007:269) mostrou também como os brancos podem ocupar um lugar antes atribuído aos jaguares nos mitos kanamari. 
antigos de vestir é visto como significativo pelas pessoas, associado ao modo como elas se compreendem como "índios civilizados" (Gow 2001:129). A ideia indígena do uso das roupas como análogo a uma mudança de pele, ou de "envelope corporal", indica um deslocamento de posição diante da perspectiva do outro, que desencadeia uma metamorfose e uma mudança do próprio ponto de vista, e que é bastante comum na Amazônia (ela foi analisada por diversos autores, a exemplo de Gow 2007; Vilaça 1999; Bonilla 2007; Viveiros de Castro 2002:393; Ewart 2013a:94).

A "festa de pintação" (como são chamadas em português) entrelaça as formas e as substâncias do parentesco, ligando, como em uma fita de Moebius, consanguinidade e afinidade: a menina, após se submeter às manipulações semióticas de substâncias alógenas, operadas por suas parentes próximas ascendentes (dietas, banhos e infusões, pintura com jenipapo), oferecerá caiçuma produto arquetípico da feitoria feminina - para convidados que são recebidos por seus parentes (seus pais, seus irmãos...), vestidos como brancos. A transformação da transformação, que consiste na adoção das roupas, dos vasilhames e da música dos payrune nas festas de pintação, está associada à posição de afins potenciais que esses brancos vieram a ocupar no espaço social manxineru.

Como afirmou Viveiros de Castro (2002:447), “a construção do parentesco é a desconstrução da afinidade potencial; mas a reconstrução do parentesco ao fim de cada ciclo deve apelar para esse fundo de alteridade dada que envolve a socialidade humana”. A caiçuma forte, que se associa à animação crescente da festa, irá operar a transformação subjetiva (pois a "transformação da subjetividade" é o núcleo da experiência de estar bêbado, himru - Gow 2001:140-144), que permitirá a abertura dos grupos locais aos afins. No embaralhamento que a bebedeira progressivamente promove, afins potenciais se tornam afins atuais (e eu mesmo era chamado de "primo", quando a bebedeira se instalava nas festas), afins atuais (ou, casos mais raros, parentes próximos) se estranham e se tornam inimigos através das brigas que sempre ameaçam irromper a cada festa (e contra as quais os donos da festa não cansam de admoestar os convidados), e uma grande quantidade de energia sociológica é produzida pelo atrito de corpos e palavras ébrios, originando fatos e afetos que alimentarão as fofocas e as conversas nas semanas seguintes.

\section{FESTA DE DANÇAR OU HANSALU}

As festas, contudo, não se restringem à "pintação", sendo que, periodicamente, as pessoas se organizam em festas de dimensões variadas. Como já observei, em língua manxineru, as festas são chamadas de hansalu, palavra derivada do 
português "dançar". Enquanto estive nas aldeias no alto rio Iaco, eram raras as semanas nas quais nenhuma festa acontecia. Quase tudo pode ser um motivo de comemoração, mas os que encontrei como mais comuns durante o tempo que passei entre os Manxineru poderiam ser divididos em dois grupos: os motivos pessoais, que ensejam festas particulares e, por vezes, mais restritas, realizadas na casa de alguém, como o aniversário de filhos pequenos (em contraposição ao aniversário das pessoas adultas, que parece quase nunca ser comemorado), o casamento (quando o noivo ou os pais da noiva e do noivo estão animados para fazer festa) ou a "pintação" de uma filha; e as festas mais "públicas", cujo motivo se formula na linguagem sociológica das aldeias e de suas lideranças, por exemplo o encerramento dos pequenos torneios de futebol e de outros eventos ou reuniões, datas e feriados no calendário nacional (dia das crianças, dia das mães, dia do índio, natal, ano novo... dificilmente se poderia fazer uma lista exaustiva) etc. Esse último tipo de festa, ligado às motivações mais "públicas", se assemelha mais àquelas "festas de comunidade nativa", descritas por Gow (1991:221-225).

Muitas vezes, o evento é anunciado com antecedência, e parentes e amigos de comunidades vizinhas são convidados. É comum, nessas ocasiões, o oferecimento de comida por parte de anfitriões, que, nas festas particulares, consiste geralmente em produtos do roçado (arroz, macaxeira) ou da agricultura de praia (como o feijão), com a carne de algum animal de criação (porco, boi ou carneiro); e, nas festas públicas, consiste na comida do branco que vem para a merenda escolar. O imprescindível é, todavia, o oferecimento de caiçuma: dir-seia que, se a causa final de uma comemoração pode variar bastante (o aniversário de um filho, a formatura de uma turma da escola, o final de um campeonato de futebol, um casamento...), a sua causa eficiente permanece sempre a mesma - uma quantidade suficiente de caiçuma fermentada.

Nas festas particulares, o feitio de caiçuma é atribuição das mulheres da casa anfitriã; nas festas mais públicas, cada casario (ou seção residencial) oferece uma quantidade variável, segundo o gosto pela bebedeira e a vontade de colaborar. Em todos esses tipos de evento, geralmente se começa a beber durante o dia, mas a festa mesmo ocorre de noite. As pessoas se espalham, vão tomar banho e se arrumar, e depois comparecem onde será realizada a comemoração. Em todos os casos, a música, que junto da caiçuma é a condição sine qua non para que um evento seja considerado como uma festa (afinal, uma das coisas que definem a festa é a dança, hansalu), vem dos aparelhos de som movidos a bateria ou a gerador de luz, comprados na Bolívia ou no Peru, que tocam 
cartões de memória ou pen-drives cheios de forró, carimbó, brega ou (em menor medida) cúmbia.

Além da música e da caiçuma, o que nunca falta nesses momentos é o risco eminente de brigas. Como Calavia Sáez (2006:133) observou durante a sua pesquisa entre os Yaminawa, "não há festa sem briga", ainda que as brigas nem sempre cheguem às vias de fato. A bebedeira implica o esquecimento das relações respeitosas: é quando genro "bagunça" com sogro, irmãos se estranham, desconhecidos se chamam de primos etc. Assim, toda festa depende, para terminar bem, das atitudes enérgicas de seu dono, para controlar a agressividade dos convivas, daí as admoestações constantes e nem sempre eficazes, como aquelas às quais me referi anteriormente: "somos parentes e por isso não podemos brigar”. A afirmação “somos todos parentes" visa um efeito perlocutório claro: pacificar os ânimos, aumentando ao menos aparentemente a valência das relações de respeito entre parentes próximos.

Stolze Lima afirmou que, entre os Yudjá,

quando não tem cauim, as pessoas,
homens e mulheres, são caladas,
discretas, parecem tímidas. Quando
tem, amam a alegria, a conversa
ruidosa, as pessoas expansivas e
brincalhonas. Amam sobretudo ver-se
a si próprias, tão reservadas, tomadas
por uma alegria exuberante (Lima
2005:219).

Difícil dar uma descrição mais sensível do tom autorreferente, ou até narcísico, que colore a alegria que se cultiva durante uma festa. "Eu tô bêbado!" (“nimeta!”), ou "a gente tá tudo chapado" (“wimeta!"), repetiam, então, os rapazes, transparecendo orgulho de sua condição quase lamentável. A festa de pintação, como as festas de caiçuma no geral, promovem um aquecimento entrópico da socialidade (diz-se que a bebida forte esquenta), uma intensificação emocional e sociológica que estabelece o contexto da festa (ou o seu frame, sensu Bateson 1972) como extraordinário: a bebedeira é homérica, a gritaria e a diversão são excessivas, e as brincadeiras entre os afins de mesma geração ameaçam contaminar quase todas as relações. Um de meus amigos mais velhos, por exemplo, não perdia uma festa, mas sempre, depois de certo ponto, se deixava estar calado em um canto, bebendo discretamente, sem conversar com quase ninguém: ele me dizia que evitava falar com os parentes porque não tolerava que seus sobrinhos o desrespeitassem, e não tinha paciência com as brincadeiras dos bêbados. A alegria autorreferenciada da consciência de estar bêbado e a intensificação das relações jocosas que observo aqui me levam a pensar as festas de caiçuma como uma espécie de metarrito (cf. Nahum-Claudel 2013:87), isto é, como um experimento sobre a abertura dos limites e sobre as condições da socialidade - um experimento culinário, ressalte-se, cujo principal 
catalisador é produzido pelas mulheres, em suas panelas e cozinhas.

Em uma ocasião, fez-se uma grande reunião para decidir quando seria realizada uma festa para comemorar a eleição do primeiro vereador manxineru a vencer o pleito (depois de três tentativas anteriores). Alguns homens, que até então eram quem mais falavam na reunião, expressavam sua maior preocupação: providenciar uma quantidade suficiente de caiçuma forte, o que implicava, alguns diziam, esperar quatro ou cinco dias para que a massa preparada pelas mulheres fermentasse. Outros tomavam a palavra para dizer que três dias eram suficientes. Foi então que uma das mulheres resolveu acabar com a discussão: ela disse, com irritação, que são as mulheres que fazem a caiçuma, e que são elas que sabem quantos dias são necessários para fazê-la azedar. Ela, então, completou dizendo que não adiantava os homens ficarem pedindo caiçuma, porque, no final das contas, eles não aguentavam o porre e iam logo brigar uns com os outros. Seguiu-se um grave silêncio, que inevitavelmente pontuava a aceitação daquele discurso. A conversa foi sendo retomada em um crescendo: um rapaz falou, orgulhoso, que aguentava o porre, e que as mulheres podiam fazer o tanto de caiçuma que quisessem que ele ia beber tudo, mas alguma mulher disse se lembrar do dia em que o orgulhoso beberrão correra da caiçuma... Seguiram-se outras provocações animadas, e assim foi sendo combinada a festa. Três dias depois, a festa amanheceu o dia na escola, quando bebemos toda uma caixa-d'água com quinhentos litros de caiçuma forte.

Apesar de serem as mulheres as fabricantes da caiçuma forte, elas raramente bebem, e ver uma mulher embriagada é algo relativamente raro nas aldeias manxineru. Elas fazem caiçuma para seus maridos beberem e, mais ainda, para que eles deem de beber aos seus amigos e convidados. Uma forma comum de um homem convidar um primo ou qualquer parente para uma visita é dizer que ele vai pedir à sua esposa para preparar uma quantidade suficiente de caiçuma forte. Sempre há no feitio da caiçuma fermentada certa teleologia que envolve fazer outras pessoas beberem, e uma "brincadeira" (em um sentido também betesoniano, cf. M. Matos 2018b) comum entre afins de mesma geração consiste em "dar um porre" no amigo, convidando-o para uma visita, tendo já pedido às mulheres de seu casario para fazerem grandes quantidades de caiçuma forte. As esposas dão assim aos seus cônjuges a prerrogativa de oferecer a outrem a bebida, e esse dom é por eles reconhecido como um ato de atenção ou de carinho.

É verdade que a importância alimentar da caiçuma vai muito além da embriaguez, e ela, em sua versão "doce" (potshwalu), é consumida diariamente por adultos, crianças e jovens. A caiçuma é o principal 
vetor da função nutriz assumida pelas mulheres, e é assim um agente criador dos vínculos de parentesco: ela sintetiza o cuidado que as mulheres dirigem aos seus familiares e aos seus maridos. Mas a diferença entre aquela que é feita para embriagar (tepalha katsholu) e a exclusivamente alimentar (tepalha potshwalu) não é tão marcada ${ }^{15}$.

Não há diferença qualitativa entre o consumo ritual e o consumo cotidiano, já que a caiçuma forte é consumida diariamente pelos homens, de acordo com seu gosto pessoal e disposição. $\mathrm{O}$ que diferencia a caiçuma forte que se bebe diariamente em casa da que se bebe nas festas é a quantidade: as festas são avaliadas pela quantidade e pela qualidade da caiçuma que foi oferecida, e essa é a primeira informação que se escuta em qualquer relato de uma festa. Além disso, e como as pessoas sempre me falavam louvando as virtudes de sua bebida, a caiçuma forte embriaga, mas, simultaneamente, alimenta, o que compõe com certa segurança maternal que as pessoas procuram conferir às experiências etílicas na aldeia: o bêbado na aldeia está protegido, seus parentes (especialmente suas irmãs, sua mãe e sua esposa) vão zelar para que nada de ruim lhe aconteça. Esse fato era ressaltado em sua diferença explícita diante da bebedeira em contextos urbanos, quando os bêbados estão desprotegidos, e quando qualquer coisa pode acontecer com eles.

A importância da bebedeira não poderia ser menosprezada, tanto pelo gosto que os homens adultos têm de beber e de se embriagar ${ }^{16}$ quanto por aquilo que a caiçuma forte e o seu consumo fazem render. Um sumário desse rendimento foi feito por Erikson, e eu não poderia oferecer um resumo melhor:

o álcool também desempenha um papel
crucial nas esferas política e econômica.
Alianças são feitas e dissolvidas por
ocasião de festivais intercomunitários
que duram apenas enquanto duram as
reservas de bebida, que fornecem o
pretexto. Do mesmo modo, a maioria
das obras coletivas - construir uma
casa, preparar um roçado - opera
de acordo com o duplo princípio
da reciprocidade generalizada e da
retribuição 'em líquido' (rétribution
'en liquide'), no sentido mais literal do
termo. O prestígio de uma família ou
comunidade é medido pela quantidade
e qualidade da cerveja que é capaz de
fornecer. Suas faculdades produtivas
derivam disso. A vida social e a bebida
estão tão entrelaçadas que, muitas
vezes, as quantidades disponíveis
condicionam estritamente a duração
das visitas. Na Amazônia boliviana
dos Chacobo, se você chegar
inesperadamente em uma casa onde
as reservas estão esgotadas, deverá
sair do local o mais rápido possível.
As mulheres, geralmente confusas, se
apressam em se exaltar, mostrando-
lhe as bacias ou vazilhames nos quais

15 Como parece ser o caso entre os Yudjá, com seu caium feito para ser consumido ritualmente (Lima 2005:281-282), ou entre os Araweté, para os quais a caiçuma embriagante não é considerada um alimento (Viveiros de Castro 1992:119-120).

16 Quase comparável aos Ashaninka, com os quais Weiss (1974:397) estudou: "o estado psíquico ideal de um campa ribeirinho é o de inebriação". 
fermentam a próxima bebida, mas seria indecoroso permanecer. Por outro lado, se você chega em uma casa bem abastecida, é quase impossível sair até que os convidados terminem de beber (Erikson 2004:5).

O consumo da caiçuma fermentada participa de uma "política da consideração" (Kelly \& M. Matos 2019), que é imanente aos modos de relação manxineru. Esta bebida é veículo de um "agir sobre o agir" de outrem, e, através dela, as mulheres proporcionam aos seus maridos modos de transformar a subjetividade alheia. Receber uma visita e obrigá-la a beber voluntariamente grandes quantidades de caiçuma fermentada é um dos passatempos favoritos dos homens adultos. Cabe ao anfitrião oferecer a bebida, como cabe ao visitante tomar toda caiçuma que lhe é oferecida. Como se pode imaginar, essa etiqueta gera, muitas vezes, um grande constrangimento aos brancos que visitam a aldeia. Se, em certo sentido, o "saber" é uma "etologia", não interessa se é o estômago que não pode conter a caiçuma que o payri polidamente recusa, ou se a recusa vem pela insensibilidade relativa àquela etiqueta. No geral, "branco não sabe beber caiçuma".

Além disso, a caiçuma participa de uma sofisticada dinâmica da disponibilidade: ela é algo eminentemente disponível, define-se por isso. Sua falta gera constrangimento no anfitrião, e uma visita que insiste em aparecer ou em permanecer em uma situação de escassez da bebida parece pedir abertamente e deselengantemente algo que não pode ser oferecido. Ambas as situações são evitadas ou contornadas por uma diplomacia composta por inúmeros subterfúgios ou astúcias, que apenas muito desastradamente o antropólogo pôde aprender.

\section{0 CONSERVADORISMO ALIMENTAR}

É interessante observar como nas transformações da festa de pintação algumas mercadorias dos brancos (chamadas em manxineru de rejnu) puderam ser acomodadas, mas não no conteúdo partilhado que define a festa: seria impensável a realização de uma festa desse tipo na qual não se consumisse caiçuma forte (o que é, suspeito, uma das principais causas para o abandono da festa entre os Manxineru convertidos pela Missão Novas Tribos ${ }^{17}$ ). Em certo sentido, a afinidade pode ser emoldurada pela presença marcante de roupas, músicas e vasilhames dos payrune (i.e., por elementos capturados ou trocados dos brancos, que formam um fundo de afinidade potencial), mas deve ser nutrida majoritariamente por conteúdos produzidos localmente. Em um

17 Para a discussão sobre o abandono da bebida fermentada e o ritual de iniciação feminina entre os Piro do Urubamba por influência de missionários adventistas, cf. Gow (2001:231-234). 
momento tão importante, como o término do processo de formação do corpo feminino, entendese a necessidade do provimento de caiçuma forte $\mathrm{e}$ de carne de caça (ou dos bois ou porcos atualmente criados por algumas famílias), produtos que são índices das capacidades produtivas femininas e masculinas e expressão de sua autonomia.

Devemos, aqui, observar a oposição entre a receptividade diante de certas "coisas de branco" e aquilo que chamo, por falta de um nome melhor, de “conservadorismo alimentar”. Celulares, máquinas de foto, motores, óculos escuros, espingardas e rifles, panelas, inversores, televisões, tocadores de $\mathrm{mp} 3$, roupas e perfumes, equipamentos esportivos de futebol são amplamente desejados e usados orgulhosamente nas ocasiões propícias. Alunos e professores comparecem diariamente às escolas das aldeias impecavelmente vestidos em suas melhores roupas e sapatos, perfumados e de banho tomado (não importa o quanto tenham andado ou remado para chegar à escola). A comida do branco, por sua vez, só é consumida quando se está na cidade, ou enquanto quitutes e pequenos tira-gostos (rosquinhas, balas, pedaços de queijo, refrigerante), coisas em quantidade limitada, que se come de vez em quando, quando alguém chega da "rua". Ou, excessão significativa, nos intervalos para a merenda na escola, quando se consome o macarrão, o cuscuz transgênico e os enlatados, que a Secretaria de Educação Estadual manda periodicamente para a aldeia ${ }^{18}$ - pode-se pensar que apenas uma comida marcadamente "dos brancos" poderia ser oferecida diariamente por professores ou merendeiras das escolas para crianças em relação às quais eles não mantêm qualquer função nutriz verdadeira.

No geral, não se compra comida para levar para a aldeia ${ }^{19}$; pelo contrário, é comum, quando se encontra um Manxineru na cidade, ouvir dele sobre a sua saudade da comida da aldeia e principalmente da caiçuma. Alguns itens alimentares, que, no entanto, poderiam ser considerados como "de branco", são ainda pensados como parte de uma dieta apropriada (como a "comida legítima" dos Piro - Gow 1991), e são computados na conta do estado intermediário em que eles pensam se encontrar: diferentemente dos índios isolados (ou hoja hajene, "gente da floresta"), os Manxineru comem com sal e

18 É espantosamente péssima a qualidade da merenda escolar que é enviada às escolas indígenas no Acre (e, muito provavelmente, em quase todo Brasil). Os esquemas (todo mundo sabe o que essa palavra significa nesse contexto) licitatórios fazem chegar às escolas, nas aldeias, itens alimentícios da pior qualidade: óleo e cuscuz transgênico, macarrão das marcas mais baratas, bolachas e sucos saturados de açúcar, sardinhas quase vencidas e conservas de carne feitas sabe-se lá com o que.

19 Observo uma excessão: quando as safras de arroz sofrem muito com os ataques de graúna, praga contra a qual os Manxineru têm poucos recursos, por vezes, se compram "fardos" de arroz para levar para a aldeia. Esse produto comprado é tomado como um substituto do arroz plantado nos roçados, mas ele nunca substitui a macaxeira cozida, verdadeira acompanhante da carne ou do peixe. 
apreciam o açúcar e o óleo (substitutos do gramixó e da banha de porco dos tempos do seringal). De qualquer forma, esse "conservadorismo alimentar" tem como um de seus resultados o fato de que o dinheiro oriundo dos programas de distribuição de renda (bolsa família e salário maternidade) não é majoritariamente gasto com comida, mas apenas com esses outros tipos de mercadoria, mais ou menos necessários. A progressiva inclusão das pessoas nesses programas povoou o alto rio Iaco de motores de barco e motosserra, de rádios e de caixas amplificadas, mas pouco mudou o padrão de alimentação das pessoas.

A oposição entre o desejo por aquelas mercadorias e o conservadorismo alimentar faz parte de uma teoria nativa da "mudança cultural", diretamente ligada a processos conscientemente controlados de constituição corporal: como foi registrado por Virtanen (2012:1), também me foi dito que, mesmo que possam abandonar seus rituais, suas músicas, o consumo da ayahuasca ou os mitos, os Manxineru nunca abandonariam a sua comida ${ }^{20}$.

O conservadorismo alimentar não é resultado do isolamento ou da dificuldade de acesso às mercadorias e às comidas industrializadas. Antes, ele supõe uma estética alimentar, ligada ciosamente aos modos próprios de se relacionar e ao encaixamento das funções que cumprem as pessoas em uma economia na qual o fluxo de alimentos e de objetos faz e refaz relações nutrizes e de troca, que definem proximidades e distâncias, consanguinidade e afinidade. Trata-se, como sugeriu Lévi-Strauss (2004:197), "do lugar realmente essencial que cabe à culinária na filosofia indígena”, qual seja: "por ela e através dela, a condição humana se define com todos os seus atributos, inclusive aqueles que - como a mortalidade - podem parecer os mais indiscutivelmente naturais".

No alto rio Iaco, a comida está inequivocamente ligada à valorização da autonomia, e toda pessoa adulta deve ser capaz de produzir o que come. Isso não significa, é claro, que se possa viver sozinho, mas, mesmo sem menosprezar a complementaridade produtiva que existe entre as pessoas em um casal, ou entre pais e filhos, homens e mulheres se gabam de ser capazes, em casos de necessidade, de exercerem as funções uns dos outros (o que significaria,

20 Esse tipo de colocação não significa, é claro, que os rituais, as músicas, o xamanismo ou os mitos tenham sido abandonados ou possam sê-lo sem mais. Antes, expressa a consciência, por parte de meus anfitriões, daquilo que os brancos entendem por "cultura" (Carneiro da Cunha 2009), contrapondo esse entendimento ao que, naquele momento, meus interlocutores acreditavam poder definir o que é "ser Manxineru". Vale a pena comparar essas ideias ao esforço de "descolonização" do corpo pelos Tzeltal, entre os quais, como entre os Manxineru, "um corpo descolonizado constitui o principal meio de defesa contra a subjugação política” (Pitarch 2010:124), mas que, diferentemente dos últimos, estendem essa descolonização aos códigos de beleza, elegância e às maneiras. Os povos amazônicos, como é sabido, são muito mais permissivos na adoção/predação de elementos exógenos. Importante observar que esse "conservadorismo alimentar" não é um traço universalmente partilhado pelos povos ameríndios: compare-se, por exemplo, com a forma como os Panará têm empregado os recursos advindos dos programas federais de distribuição de renda (em Ewart 2013b:42, 2013a:89 e sgs.). 
evidentemente, reduzir a vida a um necessário que nem de longe representa um estilo de vida desejável). E, ato seguido, os Manxineru se comparam favoravelmente aos outros povos indígenas no Acre (ou à imagem que eles têm desses outros povos), dizendo, com orgulho, que não precisam de projetos do governo, e que não devem nada do que têm à generosidade de algum payri. Esse tipo de juízo está ligado ao fato, aparentemente paradoxal, de que os objetos industrializados são muito desejados, mas as formas de vida social que os produzem não o são: as pessoas distinguem ciosamente o seu modo de viver e o seu ethos dos modos de vida e dos valores que elas atribuem aos payri. Em seus aspectos materiais, ouvi muito essa distinção ser feita a partir da oposição entre os regimes alimentares ("índio come é macaxeira com carne", dizia-me sempre um amigo, me perguntando se eu não sentia falta do café, do pão, do macarrão etc.), e entre a escassez de coisas e a dificuldade de consegui-las, em comparação com as facilidades da cidade - desde que se tenha dinheiro. Em seus aspectos morais, a distinção recaía muito em uma contraposição entre a sovinice e a ganância, que imperam nas cidades, em oposição à vida na aldeia, onde não se paga para comer, onde as pessoas dão comida e ajuda às outras, sem cobrar dinheiro por isso.

Essa opinião completava-se com a constatação de que os brancos não estão tão acostumados a trabalhar coletivamente no roçado, de que eles, quando podem, preferem comprar a comida a produzi-la, e de que aqueles brancos que vivem na cidade geralmente vivem separados de suas famílias, com poucos filhos. Isto é, os brancos são pensados como, de certo modo, incapazes de constituir redes apropriadas de parentesco, padecendo de todas as faltas acarretadas por essa incapacidade. Acho que também por isso meus anfitriões insistiam tanto em saber de meus próprios parentes: quantos irmãos eu tenho, se meus pais estão vivos, se sou casado e tenho filhos.

\section{COMPLEMENTARIDADE}

A boa comida, a fartura que proporciona a generosidade e também a autonomia garantida pelos modos de produção manxineru estão ligadas às formas de relação complementar que se estabelecem entre as pessoas e entre as famílias, especialmente entre homens e mulheres que se casam. Refutando a famosa equação "meat for sex" de Siskind (1973:103-104), Peter Gow mostrou que há uma simetria cruzada e complementar entre a produção feminina da caiçuma e a predação masculina da carne, que corresponde às relações específicas e aos desejos experienciados pelas pessoas reciprocamente: os homens dependem de suas mulheres para satisfazer seu desejo por caiçuma, e as mulheres dependem de seus maridos para satisfazer seu desejo por carne (Gow 1989, 1991:126). Meus anfitriões, por 
vezes, expressavam essa complementaridade em termos das responsabilidades de cada um: cabe ao homem prover a carne para a sua família, e cabe à mulher prover caiçuma (e, nessa correlação, eles se referiam não apenas à caiçuma forte ou azeda, mas também à caiçuma doce).

Em uma conversa com o amigo Lucas Artur Brasil Manchineri, minha sugestão de que se tratava de uma espécie de troca (um "meat for caiçuma") foi rejeitada, sob alegação de que o que estava envolvido era muito mais do que o oferecimento de um produto com vistas à obtenção de outro: "não é uma troca, é uma responsabilidade. Se fosse uma troca, a mulher tinha que dizer: 'você vai buscar caça que eu faço caiçuma para você'. Aí seria uma troca, mas não, às vezes a mulher não manda o homem, mas ele vai, às vezes o homem não manda a mulher fazer caiçuma, mas ela faz. É uma responsabilidade”. Assim, costumava ouvir de meus amigos manxineru que iam pescar ou caçar que eles iam "procurar alguma coisa" para a esposa comer ou para seus filhos comerem. Também as mulheres dizem fazer caiçuma para seus maridos, e penso que isso aponta para uma definição daquela "responsabilidade" de que me falava Lucas: trata-se de agir tendo em vista ou pensando no outro pólo da relação complementar (assim, pais agem pensando em seus filhos, maridos pensando em suas esposas, filhos pensando em seus pais etc.). Trata-se assim, de uma relação de complementaridade, ou de relações de dependência ou de causação mútua.

A complementaridade, que é condição de uma casa enquanto unidade produtiva, depende da diferença irredutível entre homens e mulheres, que se produz e se traduz também pela divisão do trabalho, seja no cotidiano, seja no preparo para a realização de festas e mutirões. A formação de pessoas plenas - i.e., sobre quem se possa dizer como kpixkolu/o ("forte", "saudável”, "disposto", "animado") e kpoyikuneru/o ("feliz", "alegre") depende dessa mutualidade complementar.

Muito mais do que expressão de uma racionalidade econômica, ela resiste à sua metaforização enquanto uma espécie de troca. No contexto de suas relações jocosas, no entanto, primos de sexo cruzado podem expressar a ideia de trocar caiçuma por carne, e eu vi muitas vezes meus amigos se dirigirem às suas primas dizendo “cadê caiçuma forte?”, o que era prontamente respondido pelas moças com algo do tipo “cadê carne de anta?, tu não traz.... Nesse contexto, a aparente equação troquista esconde o desafio ou a insinuação jocosa de que o interlocutor não é capaz de cumprir minimamente com aquilo que se espera dele. A formulação jocosa de uma relação se dá de maneira intencionalmente inapropriada, estabilizando o contexto das relações apropriadas (i.e., respeitosas), e derivando a sua "graça" da perversão da forma “correta” de relação (cf. M. Matos 2018b). 
A reciprocidade básica entre homem e mulher em um casal, índice da complementaridade de sua relação, é uma versão da simetria que se espera nas relações entre afins, sendo, além disso, uma medida de uma certa "igualdade de gênero" que vigora nas aldeias. É preciso observar, no entanto, que relações igualitárias não implicam a equivalência e que também, como argumentou Peter Gow (1991:101-104), enquanto a produção masculina da carne de caça pode ser pensada como um tipo de procura (no espanhol ucayalino, buscar, e os Manxineru também falam da caça, em português como "procurar alguma coisa para comer"), produzir caiçuma é principalmente "fazer" ou "trabalhar" (assim, se pode dizer em manxineru: suxone tepalewata, "as mulheres fazem caimçuma"; e sheshine rujhanijitapa, "os homens procuram (rujhana) carne/caça”).

A caça e a pesca de grandes peixes, como o surubim (kayonawlu) ou o jundiá (wakawa), dependem do conhecimento e da sorte para localizar o que já é existente: animais de caça e peixes são produzidos por outros seres, por mecanismos sobre os quais se pode especular. Já a produção de caiçuma depende do trabalho para criar ou transformar materiais através do esforço cotidiano, desde o preparo do roçado até o plantio, a colheita e a sua feitura nas cozinhas das casas. Assim, se a caiçuma é a quintessência da produção, pensada como resultado do esforço e do suor, dependente da saúde de um corpo construído como forte e capaz ${ }^{21}$, a caça é resultado da sorte e do conhecimento, para o qual concorrem a experiência pessoal e a aliança com potências estrangeiras, como a relação com os donos dos bichos e com o aprendizado do uso de certas plantas.

\section{7. À GUISA DE CONCLUSÃO}

Esses aspectos complementares das atividades produtivas não deveriam nos levar a pensar, no entanto, que seria possível repetir para os Manxineru aquilo que certa vez foi atribuído aos Huni Kuin do alto rio Purus: que aos homens cabe a captura dos elementos estrangeiros necessários para a produção da socialidade, enquanto as mulheres cuidam da produção ou da "domesticação" do mundo na aldeia (cf. McCallum 1999); ou, ainda, que "a agência masculina inclui manter relações de troca com o 'exterior', enquanto a feminina envolve transformações no “interior”" (McCallum 2000:391)22.

21 A experiência de plantio nos roçados entre os Manxineru distingue-se assim daquela de outros povos amazônicos para os quais as plantas do roçado ou os seus espíritos-donos oferecem perigos às pessoas, como é o caso entre os Candoshi e os Jívaro (Surrallés 2003:30). As razões que afastam a mulher menstruada ou grávida dos roçados manxineru, por exemplo, objetivam preservar os cultivares, e não proteger a mulher.

22 Para uma crítica desde dentro da "panologia" dessa forma de pensar a especificidade das agências masculinas e femininas, cf. B. Matos (2014:107-108). 
Se o trabalho feminino de produção alimentar não se constitui imediatamente em uma relação com os pólos mais exógenos da socialidade, como acontece com quem caça ou pesca, as mulheres estão sempre, tanto quanto os homens, ligadas a atividades diretamente relacionadas com esse "exterior" ao qual se refere McCallum (2000) elas lidam com os espíritos que assediam sua família; elas manipulam plantas e preparos que portam relações com outros tantos espíritos; elas conversam com os payri que vêm à aldeia e participam de reuniões políticas nas cidades; e são elas, afinal, que produzem e que oferecem o catalisador daqueles "ritos dedicados à afinidade”, isto é, a caiçuma forte ${ }^{23}$.

Nas casas, não pode faltar carne nem caiçuma, e a falta eventual de um desses produtos faz com que meus anfitriões se desculpem copiosamente. A caça é adquirida por homens e circulada pela mulher - diz-se que a carne deve ser "vizinhada", isto é, compartilhada entre as casas de um casario. A caiçuma, por outro lado, é produzida por mulheres e circulada pelos homens, que convidam os outros para beber ou para os trabalhos coletivos, chamados em português de "adjuntos" (hixolune, em manxineru). Os homens convidam todos os outros homens com os quais têm alguma afinidade, e não apenas aqueles seus parentes próximos. $\mathrm{Na}$ verdade, como era de se esperar, parece ser mais divertido beber com os cunhados e com os primos (MBS e FZS) do que entre a família mais próxima: as brincadeiras, a competição alegre e a linguagem jocosa combinam mais com os estados ébrios do que o carinho circunspecto e respeitoso que vigora entre os membros de uma família legítima.

Há, então, um cruzamento interessante aqui: a caiçuma produzida pelas mulheres, índice das relações intrafamiliares de trabalho, deve ser feita circular entre os afins pelos homens, e se torna, assim, veículo de relações simétricas de afinidade entre pessoas de diferentes casarios; a carne predada pelos homens e resultado das relações que se dão no pólo mais externo da afinidade potencial é circulada entre os parentes próximos pelas mulheres, sendo, então, um meio das relações complementares de compartilhamento e nutrição entre as pessoas de um mesmo casario ou entre os parentes próximos que convivem. Como na "festa de pintação", no cotidiano das aldeias, o próximo e o distante, o familiar e o estrangeiro, a afinidade e a consanguinidade se conectam e se entrelaçam, modalizados pelos conhecimentos incorporados, que definem as agências masculinas e femininas. 


\section{REFERÊNCIAS}

Bateson, G. 1972. Steps to an ecology of mind. Chicago: The University of Chicago Press.

Belaunde, L. E. 2003. Yo, solita, haciendo fuerza: historias de parto entre los Yine (Piro) de la Amazonía Peruana. Amazonía Peruana 14(28-29):125-145.

Belaunde, L. E. 2006. A força dos pensamentos, o fedor do sangue. Hematologia e gênero na Amazônia. Revista de Antropologia 49(1):205-243. DOI: http://dx.doi.org/10.1590/S0034-77012006000100007.

Bonilla, O. 2007. Des proies si désirables. Soumission et prédation pour les Paumari d'Amazonie brésilienne. Tese de Doutorado, École des Hautes Études en Sciences Sociales, França.

Brasil, L. A. 2017. Milho massa, koshma e caiçuma: um percurso etnográfico no desenvolvimento sustentável dos Manxineru, do passado ao presente. Dissertação de Mestrado, Universidade de Brasília, Departamento de Desenvolvimento Sustentável, Brasília.

Calavia Sáez, O. 2006. O nome e o tempo dos Yaminawa: etnologia e história dos Yaminawa do rio Acre. São Paulo: Editora da Unesp.

Carneiro da Cunha, M. 2009. "Cultura" e cultura: conhecimentos tradicionais e direitos intelectuais, in Cultura com aspas, pp. 311-373. São Paulo: Cosac \& Naify.

Clastres, P. 2003. A sociedade contra o Estado: pesquisas de antropologia política. Trad. Theo Santiago. São Paulo: Cosac \& Naify.

Costa, L. 2007. As faces do jaguar: parentesco, história e mitologia entre os Kanamari da Amazônia ocidental. Tese de Doutorado, Museu Nacional/Universidade Federal do Rio de Janeiro, Departamento de Antropologia Social, Rio de Janeiro. 
D’ans, A. M. 1975. La verdadera biblia de los Cashinahua. Lima: Mosca Azul.

Deleuze, G., e F. Guattari. 1995. Mil platôs: capitalismo e esquizofrenia. v. 2. Coordenação da tradução: Ana Lúcia de Oliveira. São Paulo: Editora 34.

Erikson, P. (ed.). 2004. La pirogue ivre: bières traditionnelles en Amazonie. Saint-Nicolas-de-Port: Musée Français de la Brasserie.

Ewart, E. 2013a. Space and society in central Brazil: a Panará ethnography. London: Bloomsbury.

Ewart, E. 2013b. Demanding, giving, sharing, and keeping: Panara' ideas of economy. The fournal of Latin American and Caribbean Anthropology 18(1):31-50. DOI: https://doi.org/10.1111/jlca.12002.

Gow, P. 1989. The perverse child: desire in a native Amazonian subsistence economy. Man, New Series 24(4):567-582. DOI: http://dx.doi.org/10.2307/2804288.

Gow, P. 1991. Of mixed blood. Kinship and history in Peruvian Amazon. Oxford: Claredon Press.

Gow, P. 2001. An Amazonian myth and its history. Oxford: Oxford University Press.

Gow, P. 2007. La Ropa como Aculturación en la Amazonía Peruana. Amazonía Peruana 15(30):283-302.

Gow, P. 2016. Jeronimo's declaration of independence, in Freedom in practice: governance, autonomy and liberty in the everyday. Editado por M. Lino, e H. Wardle, paginação irregular. New York: Taylor and Francis, edição eletrônica.

Kelly, J. A., e M. A. Matos. 2019. Política da consideração: ação e influência nas terras baixas da América do Sul. Mana 25(2):391-426. DOI: http://dx.doi.org/10.1590/1678-49442019v25n2p391. 
Lévi-Strauss, C. 2004. O cru e o cozido. Trad. Beatriz Perrone-Moisés. São Paulo: Cosac \& Naify.

Lima, T. S. 2005. Um peixe olhou para mim: o povo Yudjá e a perspectiva. São Paulo: Editora da Unesp.

Maizza, F. 2012. Cosmografia de um mundo perigoso: espaço e relações de afinidade entre os farawara da Amazônia. São Paulo: Nankin Editorial/Edusp.

Manxineru. 2016. Shinikantshi Kosekatshri Shima Mwajnutu Tshijne Tshinanu. Rio Branco: Comissão Pró-Índio do Acre.

Matos, B. A. 2014. A visita dos espíritos: ritual, história e transformação entre os Matses da Amazônia brasileira. Tese de Doutorado, Museu Nacional/Universidade Federal do Rio de Janeiro, Departamento de Antropologia Social, Rio de Janeiro.

Matos, M. A. 2018a. Organização e história dos Manxineru do alto rio Iaco. Tese de Doutorado, Universidade Federal de Santa Catarina, Departamento de Antropologia Social, Florianópolis.

Matos, M. A. 2018b. Parentesco por brincadeira no alto rio Iaco. Anuário Antropológico 43(2):207-228. DOI: https://doi.org/10.4000/aa.3249.

McCallum, C. 1999. Aquisição de gênero e habilidades produtivas: o caso Kaxinauá. Revista Estudos Feministas 7(1-2):157-175.

McCallum, C. 2000. Incas e Nawas: produção, transformação e transcendência na história Kaxinawá, in Pacificando os brancos: cosmologias do contato no Norte-Amazônico. Editado por B. Albert, e A. Ramos, pp. 375-401. São Paulo: UNESP/Imprensa Oficial do Estado.

McCallum, C. 2001. Gender and sociality in Amazonia. How real people are made. Oxford: Berg. 
Mercante, M. 2000. A seringueira e o contato: memória, conflitos, situação atual e identidade dos Manchineri no sul do Acre. Dissertação de Mestrado, Universidade Federal de Santa Catarina, Departamento de Antropologia Social, Florianópolis.

Métraux, A. 2013. Rites de Passage des Indiens Sud-Américains: Lá Puberté Féminine, in Écrits d'Amazonie: cosmologie, rituels, guerre et chamanisme, pp. 335-348. Paris: CNRS Editions.

Nahum-Claudel, C. 2013. Working together for Yankwa: vitalising cosmogony in Southern Amazonia (Enawene-Nawe). Tese de Doutorado, University of Cambrigde, Inglaterra.

Opas, M. 2008. Different but the same: negotiation of personhoods and christianities in Western Amazonia. Tese de Doutorado, Turku University, Finlândia.

Pitarch, P. 2010. The jaguar and the priest: an ethnography of Tzeltal Souls. Austin: University of Texas Press.

Siskind, J. 1973. To hunt in the morning. New York: Oxford University Press.

Surrallés, A. 2003. Au coeur du sens: perception, affectivité, action chez les Candoshi. Paris: Éditions de la Maison des Sciences de l'Homme.

Strathern, M. 1988. The gender of the gift: problems with women and problems with society in Melanesia. Chicago: University of Chicago Press.

Vilaça, A. 1999. Devenir autre: chamanisme et contact interethnique en Amazonie brésilienne. fournal de la Société des Américanistes (85):235-260.

Virtanen, P. K. 2012. Indigenous youth in Brazilian Amazonia: changing lived worlds. New York: Palgrave Macmillan. 
Viveiros de Castro, E. 1992. From the enemy's point of view: humanity and divinity in an Amazonian society. Trad. Catherine V. Howard. Chicago: The University of Chicago Press.

Viveiros de Castro, E. 2002. A inconstância da alma selvagem e outros ensaios de antropologia. São Paulo: Cosac \& Naify.

Walker, H. 2013. Under a watchful eye: self, power, and intimacy in Amazonia. Berkeley: University of California Press.

Weiss, G. 1974. Campa Organization. American Ethnologist 1(2):379-403.

Weiss, G. 1975. Campa cosmology: the world of a forest tribe in South America. New York: The American Museum of Natural History. 